\title{
Reflections
}

\section{Islam as "The Middle Path"}

\author{
Larry Poston
}

\begin{abstract}
This article describes an observable pattern in Westem converts' journey to Islam. It shows how at an early stage in their life, many Westerners are disenchanted with their religion, Christianity or Judaism, and proceed to explore radical alternatives including new age religion, eastern religions and even various cults. Their search for spiritual and religious identity is usually not satiated by these alternatives and so they gradually gravitate toward Islam. The author argues that in Islam these converts find reason, order, meaning, and a contemporary relevance that is missing in western as well as eastern religions. It is the opportunity to traverse the "Middle Path," familiar yet new, similar yet different, which the author suggests may well be the reason why these "seekers" eventually find whatever they are looking for in Islam.
\end{abstract}

The conversion of Westerners to the religion of Islam follows an observable pattern involving readily identifiable stages, including: deliberate rejection of the religion of one's upbringing or cultural surroundings (for Westerners, Christianity and Judaism); a subsequent period of several years characterized by experimentation with religious systems (usually Eastern religions such as Hinduism and Buddhism or their derivatives) which represent a radical departure from the rejected religion; dissatisfaction with and eventual rejection of the radical alternatives; and conversion to Islam as a movement from an extreme departure back in the direction of the religion that was originally rejected. Thus for many converts, Islam is a "mid dle way" between two unacceptable poles, or, to use the terminology of philosophers, a synthesis rooted in a practical Hegelianism.

The purpose of this article is to describe in detail each stage of the above-mentioned process, including reasons cited by Westerners for the unacceptability of contemporary expressions of both Christianity and Judaism, as well as reasons for the eventual rejection of radical alternatives. 
The features of Islam that allow it to be characterized as a "middle path" will be highlighted in the concluding section.

The case studies cited in the essay originally formed the basis of a much larger study of conversion to Islam conducted by the author in 1987 and 1988. Accounts of the religious experiences of 34 Americans and 38 Europeans were collected and subjected to statistical analysis for the purpose of determining a profile of the "typical" convert to Islam. Results of this study are available elsewhere and will be used only as background information for the present discussion. ${ }^{1}$

\section{Stage 1: Rejection and Apostasy}

In recent years, a great deal of information has become available regarding the disaffection of Westerners with the religious traditions that have come to be considered intrinsically "Western," i.e., Christianity and Judaism. California sociologist Wade Clark Roof has shown in his study of A Generation of Seekers how "baby-boomers" (persons born between 1946 and 1964) have been particularly susceptible to this trend. According to his findings, two-thirds of the persons within this age range abandoned the faith of their parents or their surrounding culture during their teens. Of those who drop out, less than one in four return to active participation in a place of worship. ${ }^{2}$

Christians have suffered far heavier losses than have the Jewish people. Disaffection with Judaism does not appear to be as common as does withdrawal from the various expressions of Christianity. In a study designed to determine the faithfulness of adherents to specific religious groups, Roof and C. Kirk Hadaway discovered that members of the various Jewish sects were the least likely to convert to some other religious system, with an 83.9 percent rate of perseverance. ${ }^{3}$ Several factors contribute to this phenomenon, most notably the tight cohesion that exists between Jewish religion and culture and the close bonding created among adherents to Judaism through the centuries due to prejudice and persecution. But it is noted that certain aspects of contemporary Judaism are rapidly becoming highly problematic for Westerners. The hypocrisy of nominalism, the legalism of ritualistic practices, and the militancy of Zionist politics are most often cited as reasons for leaving the faith. The general trend toward secularization within Western society plays a role as well. This is particularly true with Jewish young people, many of whom are constantly pressured to conform to the values and practices of Westem culture and for whom bonding due to prej- 
udice and persecution has not been as strong as it was for previous generations. For these reasons, apostasy from Judaism is on the rise.

The most recent studies have shown that only 11 percent of baby boomers currently attend a church or synagogue regularly and that up to 70 percent of U.S. citizens under age 30 have no religious training at all.

To what may be attributed this general dissatisfaction and malaise? There are many factors, to be sure, but the most significant seems to fall under the following categories:

1. Dissatisfaction or disillusionment with the institutional aspects of Christianity or Judaism. The inherent conservatism and rigidity of most church and synagogue structures and their association with an era considered by many to be archaic and unenlightened led to a general disbelief in their relevancy to contemporary society. Representative of this trend is B. Davis, who was raised a Methodist and converted to Islam at the age of 18 . Davis observed that

[the Christian] religion was detached from ordinary life like a best suit - only to be displayed on Sundays ... Christianity seemed to be unable to deal with the present crisis. It tried to drug its adherents by means of incense, lights, colored vestments, long litanies to the "saints" and all the other trappings of Romanism. It did not try to concern itself with what went on outside the church. ${ }^{4}$

P.E. Chipperfield, although converted at a much older age, had a similar evaluation of Christianity, he "had found that the religion of [his] upbringing failed to meet the conditions [he] found in the outside world." And a British citizen who now calls himself Hussain Rofe has a similar testimony conceming the Judaism in which he was raised:

I learnt, much [from Judaism], but rejected much. Following all the rules and prescriptions would have left little time for attending to any secular affairs. The mind would have had to be concentrated on endless forms and rituals. Worst of all, it was for a minority and led implicitly to the creation of a gulf between different social groups. ${ }^{6}$

2. Dissatisfaction with the theological doctrines or ethical teachings of Christianity or Judaism. Both religions are generally considered to be needlessly and hopelessly complex with regard to doctrine and praxis. The multiplicity of denominational options available within Protestantism, for instance, is bewildering to many. In addition, the ethical teachings of these faiths have become increasingly at odds with the lifestyles of the majority 
of Westerners, most noticeably in the areas of sexuality and gender issues. Jeanette Hill, for instance, writes in the account of her conversion that

it appeared that I should have to believe in the Holy Trinity. ... This alone set me doubting, for I could not believe Jesus to be the Son of God in that sense. ... [Also,] life as a whole was not the theme of the New Testament. Teachings of extreme mercy and forgiveness, if applied to daily life, would not work, and these could not form the basis of any human society?

Feysal Wagener believes that Christian doctrine retarded his personal growth. "Dogmas," he says, "such as Original Sin, the Trinity, the Atonement, etc., remained for me a constant source of inner doubt and unrest and prevented me from becoming a well-balanced personality." ${ }^{8}$ And Margaret Marcus, formerly of New York City and now a resident of Pakistan writes that she was "repelled by the narrow parochial-mindedness of the synagogue and horrified by the atrocities of Zionism against the indigenous Arabs of Palestine." ${ }^{, 9}$ In a separate article she provides further details concerning her disillusionment:

Zionism is a combination of the racist tribalistic aspects of Judaism with modern secular nationalism. Zionism was further discredited in my eyes when I discovered that Israeli leaders such as David Ben-Gurion are not observant Jews and that perhaps nowhere in the world is orthodox Judaism regarded with such contempt as in Israel. The Zionists have made the worst aspects of Western materialistic philosophy their very own. Only a complete rejection of all moral and spiritual values could account for such a systematic uprooting of an entire people from thejr homeland and an utter disregard of any sense of justice. When I found that nearly all important Jewish leaders supported Zionism and felt not the slightest twinge of conscience for the terrible wrong inflicted on the Arabs, I could no longer consider myself a Jew. ${ }^{10}$

3. Disappointment in or disillusionment with the adherents in general and the leadership in particular of these faiths. Margaret Poloma, professor of sociology at the University of Akron, observes that "people in [church] leadership positions are out of touch with the people in the pews." "The leadership of mainline Christian denominations have come under particular criticism, having "failed to transmit a compelling Christian message to their own children or to anybody else." ${ }^{\prime 2}$ Hussain Rofe found in Roman Catholicism "too much mystification and subjection to human 
authority, often manifestly displaying frailty inconsistent with the semidivine status advised for the Pope and his henchmen." 13 Wadiah al-Amin felt that whenever she attended a Christian service, she was "being entertained by a great professional and not someone inspired by the light of God." 14 And Jeri Goldberg asks rhetorically:

Why do Jewish kids mess up their lives with drugs and look to mystical Eastern religions for truth? For the same reasons many Gentile kids do. Their parents go to synagogue or church and come home to quarrel and beat up one another. The kids can't see any deep reality there. ... My mother had been married three times. Among my friends I didn't know anyone who had a happy home. ${ }^{15}$

For all of these reasons, a break is made with the religion of one's childhood, and it is important to note the age at which this break occurs. In the closing years of the 19th century, Edwin Starbuck showed that the average age of conversion experiences within Christian contexts was approximately 16 years, and subsequent research has shown that is still the case in today's society. ${ }^{16}$ In the case studies presently under consideration, 11 individuals claimed that there came a specific point in their lives when they consciously and deliberately rejected the faith with which they had been raised. Several mentioned the age at which this occurred, the average being 16.8 years. It can be inferred from this that there is a group of people who remove themselves from the dominant religion of their culture at almost the same time other persons are committing themselves to that faith.

\section{State 2: Moratorium and Experimentation}

What options are available to those who have apostatized from religious communities? Obviously, these persons could choose to become agnostic or atheistic, but statistically speaking, very few do so. Most appear to enter a stage of life designated by sociologist Erik Erikson as a "moratorium period." Instead of using the religious faith in which they were raised as a framework for the adolescent integration process that results in the formation of a complete identity and worldview, some persons opt to retreat to a situation in which they can work on the process of integration at their leisure. During this period of their lives, these individuals are characterized by a hesitation to commit themselves deeply to any one religious expression.

They experiment instead, and the objects of their experimentation are most often religious expressions that deviate markedly from the 
Christianity or Judaism in which they were raised. Exotic Eastern religions - Hinduism, Buddhism, and their New Age derivatives - attract the greatest numbers.

Much has been written concerning the reasons for the attractiveness of Eastern religious systems. Jacob Needleman attributes interest in these alternative faiths to their ability to reunite the mind and the will, aspects of human personality that have been separated by the dogmas of Christianity and Judaism. Eastern faiths reintroduce the practical techniques, methods, and disciplines that have been either diluted or done away with by Western faiths, and create enormous optimism with regard to the potential that humans have for self improvement. ${ }^{17}$ Further, Carl Raschke sees the interest in the East to be a result of the rejection by Westerners of a time consciousness that has been artificially imposed upon human beings who are more geared to the timelessness of eternity. Such a concept is recovered in the essentially Gnostic monism and cyclical time concepts of Eastern philosophies. $^{18}$

The time spent in the moratorium stage can be lengthy. Forty-one of the converts to Islam in the present survey reported their age at the time of their conversion, the average being 31.4 years. If the figure of 16.8 years is used as the average age at which the religion of one's upbringing is rejected, this gives an average of 14.6 years during which individuals are experimenting with alternatives or neglecting religious practices entirely. Thomas Clayton, for instance, mentions "a considerable period of religious dormancy" following his rejection of Christianity. ${ }^{19}$ And a more or less classic statement of this aspect of the study is found in the testimony of Jeannette Hill:

At the age of 14 or 15 years it is customary for a child to renew his vows which were originally made for him or her at the time of Baptism. However, by this time I had been attempting to reason out the lessons I had been taught on Christianity, and could not help questioning the things I had been asked to believe. ... As I was not being pressed to become confirmed, I decided to postpone the matter until I could genuinely believe in the vows I should have to take. ${ }^{20}$

While few subjects gave detailed accounts of their activities during this period, some made it clear that they had experimented with more than one faith. A few indicated that they had gone from one group to another, always seeking a proper "fit" but seemingly unable to find it. Most of the religions mentioned by name are Eastern in orientation. Hussain Rofe tried both 
Hinduism and Buddhism, as did Mavis Jolly. ${ }^{21}$ Margaret Marcus stated that she studied the beliefs of all the major faiths. Muhammad Alexander Russell Webb (often called "the first American Muslim") was led to inquire into the nature of Eastern religions and philosophies, beginning with a study of Buddhism. ${ }^{22}$ The former Cat Stevens, now known as Yusuf Islam, "searched through Eastern religions and philosophies, from Buddhism and Zen, meditation, astrology, numerology and vegetarianism." 23 Wieslaw Zejierski "studied the ideologies of different religions, in particular the history and principles of Quakerism, Unitarianism, Buddhism and Baha'ism."24 And Jalal-ud-Din Howe says, "I explored further and left Christian circles, flitting like a moth from one flame to another. Buddhism, Confucianism, Taoism, Yoga, Hinduism, Sikhism ... but I was [always] weary, sick at heart." 25

Not all of the subjects gave themselves to the extremes of Eastern faiths. Some chose instead to explore the more unorthodox forms of Christianity. Patricia Horton, for instance, was raised an American Baptist, but then jumped in rapid succession to Eastern Orthodoxy, Mormonism, and finally Seventh Day Adventism. Wadiah al-Amin tried "Born-Again Christianity," "Non-denominational Christianity," Catholicism, and Jehovah's Witnesses before her conversion to Islam. ${ }^{26}$ It is clear, then, that the moratorium period for many of these subjects was not a time of spiritual inactivity. On the contrary, the aspect of "seekership" as described in the famous study by John Lofland and Rodney Stark appears to have been heightened. ${ }^{27}$ But the sense of peace and inner satisfaction that these persons sought proved to be extremely elusive.

\section{Stage 3: Dissatisfaction and Rejection}

Researchers have noted that Westerners who convert to Eastern-oriented religious do not remain in these groups for long periods of time. In a census of nine new religious movements conducted in Montreal in the early 1980s, Frederick Bird and Bill Reimer distinguished between what they called "committed members" and "transitory affiliates" (or "associates"). They discovered that 95 percent of the 29,000 persons participating in these groups could be classified as associates rather than members. ${ }^{28}$ Indeed, within some memberships only the leadership could be characterized as having an exclusive commitment to the beliefs and practices of their respective groups. Associates retain their flexibility and can thus move much more easily into and out of groups than can the more committed 
adherents. From the number of temporary commitments made by the subjects of the study prior to their conversion to Islam it appears obvious that many, perhaps most, would fall into the "associate" category.

The dropout rate of associates is enormous. Bird and Reimer found that "75.5 percent of all who had ever participated in these movements were no longer participants." In assembling statistics for a number of groups, including Transcendental Meditation, the Martial Arts, several Buddhist groups, the Divine Light Mission, Baha'i, Yoga, and Scientology, none was found to have less than a 55 percent drop-out rate, and, in one case, the rate was 100 percent.

Why is the commitment to these groups so tenuous? Bryan Wilson gives five reasons for the high dropout rates: the failure of a group's ideological pronouncements to find confirmation, an incompetent leadership leading to failure of control and communication, aspects of organization and institution that are incompatible with the spiritual message of the group, appeal to a constituency that is too narrow, and a tendency toward institutionalization that eventually overtakes all organizations..$^{29}$ Robert Balch breaks down the actual defection process into a series of nine stages, including the appearance of a "crack" in consensual validation, experiences, vacillation, disaffection, behavioral disengagement, departure, "floating," reentry, and cognitive reorganization. ${ }^{30}$

While none of the converts to Islam provided enough detail to test with certainty the above observations, available evidence suggests that they are valid. Hussain Rofe tells of his in-depth studies of the Upanishads and of Vedanta, and of his eventual rejection of Hindu philosophy because "social evils were not solved, and the priestly caste was favored with innumerable privileges, while none stretched a helping hand to the poor-outcast." Nishikanta Chattopadhyaya, a British subject raised a Hindu but trained in Western philosophy and who switched first to the Brahmo Samaj and then to Buddhism, said of the latter that "here was a system of philosophy enjoining on me to deny some and to entirely suppress others of the most natural instincts ... there must be something morbidly and radically wrong in a system and a creed that goes against our human nature." ${ }^{31}$

\section{Stage 4: Conversion to Islam}

As noted above, defection from a particular religious expression does not in most cases lead to atheism or agnosticism. The personalities under consideration consistently exhibit at least two of the traits that Lofland and 
Stark noted in their study: seekership and a religious problem-solving perspective. ${ }^{32}$ These two traits serve to keep the subjects involved in their pursuit of religious truth. One would expect, however, that such a pattern of joining and then rejecting would eventually take its toll on any individual. Consider the observation of Balch that

even when members had made a carefully reasoned decision to defect, the transition back to "civilian" life was almost always a painful process. The initial burst of exhilaration that often followed defection quickly gave way to disorientation, indecisiveness, and depression. Life outside the cult seemed shallow materialistic, and defectors often had trouble coping with the simplest responsibilities. ${ }^{33}$

Most defectors eventually return to their hometowns, but only after a delay of several months due to the fear of facing family members and old friends. When this is repeated time and time again the subject naturally finds it increasingly difficult to adjust to new circumstances. The desire to find a religious expression that truly satisfies and in which one can permanently remain grows stronger. By the time many of the subjects encountered Islam, they were psychologically predisposed to end the cycle of acceptance and rejection and to commit themselves on a more permanent basis.

In what ways did these subjects encounter Islam? At first glance, their testimonies seem to indicate that there was an enormous variation with no common pattern. But on closer examination, two factors stand out as being most significant. Of fundamental significance is personal contact with a Muslim acquaintance or friend. This does not refer to contact with a Muslim "missionary," i.e., a Muslim who deliberately conducts himself or herself in such a way so as to win converts to the faith. Only one of the seventy-two subjects of the present study mentioned the influence of such a missionary agent. All others gained an experiential knowledge of Islam by watching neighbors, chatting with acquaintances, and through other forms of casual social contact. Wadiah al-Amin mentions a chance encounter with "a couple who happened to be visiting their sister's house." Steve Johnson, while a student at Indiana University, was befriended by a student from Abu Dhabi who eventually became his roommate. ${ }^{34}$ Besides these, seventeen other converts mentioned specific individuals with whom they had come in contact and to whose lifestyles, they had been attracted. Nine of these persons came into contact with Muslims through having served in the 
military or through employment in an international business agency in a Muslim country.

The second significant factor was exposure to Islamic literature of some kind, including the Qur'an. Twenty-three converts mentioned their study of such literature to be the deciding factor in their decision making. This approach allows for a much more careful and deliberate conversion process. In most verbal confrontations with evangelistic intent, one is forced to make a decision within a very short span of time; thus many of the "classic" conversions to Christianity are characterized as "spontaneous." Exposure to literature allows one to proceed at his or her own pace.

\section{Conclusions}

Why does Islam become the alternative that many Westerners finally settle upon? It may be suggested that this religion represents a "middle path" between the religions of Christianity and Judaism on the one hand and the extremism of Eastern religions or cults on the other. Casting the phenomenon in Hegelian terms, Islam becomes a synthesis constructed from the rejection of the original thesis (i.e., Christianity or Judaism) followed by rejection of an antithesis (i.e., one or more Eastern religious alternatives). There are at least three significant features of such a synthesis.

1. Islam becomes a middle point between East and West, being essentially neither the one nor the other. In contemporary Muslim apologetics, Islam is clearly distinguished from both Christianity and Judaism, the so-called "religions of the West." Muslims are taught that neither the Tanakh nor the New Testament as they currently exist are trustworthy as revelations from the one true God. The Jewish people allegedly rewrote their history, transforming the original revelation given to them into a parody of truth. The early Christian church councils continued these revisionist tendencies with their additions of such doctrines as trinitarianism and the divinity of Jesus. Over these distortions of truth is set the religion of Islam, which claims to have the true Word of God in the Qur'an.

According to Lofland and Stark's observations regarding "extra-cult-affective bonds" and "seekership," such a demarcation would be psychologically satisfying to the convert to Islam. The first of these concepts posits that the disapproval of a person or persons with whom the subject has a negative relationship (e.g., parents) becomes, through a reverse psychological process, motivation for a deeper involvement with a nontraditional group. "Seekership" is the term used to describe the propensity of 
a subject for seeking a religious framework with which to construct a worldview and a personal identity. Recall that the subjects of the present study deliberately rejected Christianity or Judaism, at least partly due to their connection and identification with parental authority, lifestyle, and worldview. They also rejected Eastern faiths as too extreme, but were still seeking a religious paradigm with which to complete the life integration process. Thus the necessity arose for a religious faith that was not Eastern but which also did not a return to the worldview. Islam became a nearly ideal alternative, being no more acceptable to Christian and or Jewish parents than were the earlier Eastern alternatives, and, in some cases, even less acceptable.

Concerning the attractiveness of specific aspects of Islam I will only briefly describe them here. First, Islam is a man's religion. It is not plagued with the phenomenon that Christianity has had to deal with since its earliest days: the fact that females are far more likely to convert to the Christian faith than males. The virility and "warrior" image of the Muslim male combined with an unequivocal rejection of Western society exercises a strong appeal to many Western males and, interestingly enough, to some American females. ${ }^{35}$ Islam also is a religion of individuality and independence, with no necessity for mediators such as priests or pastors. Its institutional ties are of an optional nature, in contrast to Christianity and Judaism, in which the church and the synagogue play roles in the religious life. Islam is also "this-worldly" in the sense that it has a political, economic, and social agenda for the "here and now" as opposed to the promise of a futuristic kingdom to come.

In addition, Islam clearly distinguished itself from Christianity and Judaism in the area of race relations. It is not the religion of white slave traders; it has not maintained its institutions as strongholds of segregation, and it has not assumed the role of a "chosen people" displaying an arrogant and separatist attitude. Finally, Islam has made a strong case for itself as a supremely rational religion, lacking the irrationalism and even magical orientation of such Christian doctrines as the Trinity, the incarnation, transubstantiation, and the like.

But if Islam is qualitatively distinct from Christianity and Judaism, it is even more distinct from Eastern religious alternatives. The Muslim God is indeed One, but $\mathrm{He}$ is personal. Missing entirely is the undefinable monism of a Brahman concept or the ambiguity of pantheism. While Muslims have sometimes been accused of portraying Allah in terms deemed to be too 
transcendent, at the core of the various expressions of the faith there always exists a God who displays the attributes of intelligence, will, and emotion. In Islam, God interacts with humans; he communicates with them by means of His Book, His angels, and His prophets. Thus, there is a moral order that can be quantified, applied, and taught, rather than an amoral, nonpersonal concept that is beyond the boundaries of such terms as "good" and "evil."

Because of a belief in these attributes, Muslims hold a worldview that is endowed with purpose and meaning. History is linear, not cyclical. There exists for the Muslim no endless turning of the wheel of Samsara, nor is there the helpless fatalism connected with karmic law and the transmigration of souls. Humankind is headed in a specific direction. There will be an ending: a final resurrection leading to a final judgment followed by a state of eternal existence. And existence is real. It is not expressed in terms of the "snuffing out of a candle" or "absorption into an all-encompassing oneness." Individual identity, and thus individual dignity, are preserved throughout eternity. In addition, life here and now is real, to be dealt with and shaped as it is.

2. Islam becomes a support group of international proportions. Although Lofland and Stark's observations regarding extra-cult-affective bonds are significant, they represent only one aspect of human psychology. Doubtless it is true that, for the sake of proper identity construction, some persons need to make a radical break with the religious faith of their parents. And no doubt it is also true that some of this number are quite satisfied to identify with a numerically small cult that is partially or completely isolated from society. Such a situation can be quite functional if it can be reasonably maintained that one has become part of an elite group, to which special knowledge or "revelation" have been entrusted. But, as noted above, Eastern religious groups are often characterized by less than adequate leadership and a high rate of turnover on the part of adherents. The core group that is truly dedicated to the tenets of any of the faiths appears to be tiny to the point of insignificance.

From comments made by several of the converts, it would appear reasonable to conclude that a majority need to feel that the alternative religious system they have chosen has the approval and support of more than (relatively speaking) a handful of their fellow human beings. Islam supplies this need. Hussain Rofe, for instance, rejected his original Judaism for this reason, stating that "worst of all, [Judaism] was for a minority and led implicitly to the creation of a gulf between different social groups." ${ }^{36}$ Nishikanta 
Chattopadhyaya spoke of the privilege of belonging to "that great community [of Islam]," and P.E. Chipperfield titled the story of his conversion "Why I Joined the World Brotherhood of Islam." Jalal-ud-Din Howe found comfort in being lost in the immensity of Islam: "On the occasion of the "Id Festival ... I was officially received into the Brotherhood of Islam, by declaring my faith before a great congregation of Muslims, and so here, I am just another Muslim." ${ }^{37}$ In becoming a member of an Eastern-oriented cult, one is often forced to sever most, if not all, of one's earthly ties. Islam, however, initiates one into a worldwide network that provides a consistent affirmation of the rightness of the decision to convert.

3. Islam provides a sense of sentimentalism as certain familiar aspects of one's childhood are recovered. Islam's fundamental elements evoke memories of a simpler, happier time of childhood innocence, of Sunday school and catechetical classes for some, of conversations overheard on sunny front porches between grandfathers and uncles or others. In Islam one renews an acquaintance with familiar figures that are completely absent in Eastern religious alternatives. Instead of the unpronounceable titles of Eastern deities, the old familiar names of Adam, Abraham, Moses, David, Mary, Jesus, and Gabriel are revived. Each of these is subtly different, to be sure, but they are names that the subject knows. The same is true with the concepts of a personal God, the efficacy of good works, a final judgment, a resurrection, an eternal heaven and an eternal hell. These are familiar; they are understood and can be dealt with.

Of course the question remains, How well does Islam function as a "middle path" over a longer period of time? Will those who have converted to the faith for the reasons mentioned above find it to be an adequate synthesis for the remainder of their lives or will their search continue? Since no recent studies exist concerning the phenomenon of apostasy from Islam, it is possible to predict what the long-term results will be. But it appears that for an increasing number, the Muslim faith has become a long-sought, happy medium between two unacceptable extremes, and thus the Shari'ah path has become "the path of the middle way."

[Editor's Note: Though not in an identical context, nevertheless, the Qur'an says: "Thus we have appointed you a middle nation so that you may be witness over the nations" (2:143).]

\section{Notes}

1. See Larry Poston, Islamic Da'wah in the West: Muslim Missionary Activity and the Dynamics of Conversion to Islam (New York: Oxford University Press, 1992). 
2. See Wade Clark Roof, A Generation of Seekers (San Francisco: Harper San Francisco, 1993).

3. Wade Clark Roof and Christopher Kirk Hadaway, "Denominational Switching in the Seventies: Going Beyond Stark and Glock," Journal for the Scientific Study of Religion (December 1979): 364.

4. B. Davis, "Why Islam Satisfies Me," The Islamic Review (November 1949): 35.

5. P.E. Sa'eed Chipperfield, "Why I Joined the World Brotherbood of Islam," The Islamic Review (June 1952): 14.

6. Hussain Rofe, "Why I Accepted Islam," Muslim News International (August 1968): 34-35.

7. Jeanette D. Salma Hill, "The Story of My Becoming a Muslim," Islamic Review (March 1954): 26.

8. Feysal W. Wagener, "Why I Joined Islam," Islamic Review (December 1952): 22.

9. Maryam Jamelah, Why I Embraced Islam (Lahore, Pakistan: Mohammed Yusuf Khan and Sons, 1978), 10-11.

10. Margaret Marcus, "How I Became Interested in Islam," The Islamic Review (April 1961): 8-9.

11. Richard N. Ostling, "The Church Search," Time (April 5, 1993): 49.

12. Ibid.

13. Hussain Rofe, "Why I Accepted Islam," Muslim News International (August 1968): 34.

14. Wadiah al-Amin, "Islam Gave Me a Sense of Dignity," Islamic Horizons (September 1979): 8 .

15. Jeri Goldberg, "Looking For Where It's At," in The New Jews, ed. James C. Hefley (Wheaton, IL: Tyndale House Publishers, 1974), 24.

16. See Edwin D. Starbuck, The Psychology of Religion (New York: Charles Scribner's Sons, 1900); F.J. Roberts, "Some Psychological Factors in Religious Conversion," British Journal of Social and Clinical Psychology (1965): 185-187; V. Bailey Gillespie, Religious Conversion and Personal Identity: How and Why People Change (Birmingham, AL: Religious Education Press, 1979).

17. Jacob Needleman, The New Religions (New York: E.P. Dutton \& Co., 1970), 14-21.

18. Carl A. Raschke. The Interruption of Eternity: Modern Gnosticism and the Origins of the New Religious Consciousness (Chicago: Nelson-Hall, 1980), 1-22.

19. Thomas Clayton, "Why I Embraced Islam," The Islamic Review (September 1949): 20.

20. Jeannette D. Salma Hill, "The Story of My Becoming a Muslim," The Islamic Review (March 1954): 25.

21. Mavis Jolly, "Why I Accepted Islam," Muslim News International (November 1968): 38.

22. Emory H. Tunison, "Mohammed Alexander Russell Webb: First American Muslim," The Arab World (1945): 15-16.

23. Russell Smith, "The Former Cat Stevens' Peace Training," Chicago Tribune (Wednesday October 28, 1987): Section 5, 3.

24. Wieslaw Zejierski, "Why I Accepted Islam," Muslim News International (February 1969): 39 .

25. Jalal-ud-Din Howe, "At the Threshold of Islam," The Islamic Review (June 1953): 33.

26. Wadiah Al-Amin, "Islam Gave Me a Sense of Dignity," Islamic Horizons (September 1979): 8.

27. John Lofland and Rodney Stark, "Becoming a World-Saver. A Theory of Conversion to a Deviant Perspective," American Sociological Review (December 1965): 862ff.

28. Frederick Bird and Bill Reimer, "Participation Rates in New Religious and Para-Religious Movements," Journal for the Scientific Study of Religion (1982): 5. 
29. Bryan Wilson, "Factors in the Failure of the New Religious Movements," in The Future of New Religious Movements, ed. David G. Bromley and Philip E. Hammond (Macon, GA: Mercer University Press, 1987), 30-41.

30. Robert W. Balch, "When the Light Goes Out, Darkness Comes: A Study of Defection from a Totalistic Cult," in Religious Movements: Genesis, Exodus, and Numbers, ed. Rodney Stark (New York: Paragon House, 1985), 1-49.

31. Nishikanta Chattopadhyaya, Why I Have Accepted Islam? (Chicago: Kazi Publications, nd.), 4.

32. John Lofland and Rodney Stark, "Becoming a World-Saver: A Theory of Conversion to a Deviant Perspective," American Sociological Review (December 1965): 862ff.

33. Robed W. Balch," "When the Light Goes Out, Darkness Comes; A Study of Defection from a Totalistic Cult," in The Religious Movements, ed. Rodney Stark: 13.

34. Steve Johnson, "Seed, Flower, Fruit: The Search that Ended in Islam," Islamic Horizons (October 1985): 5.

35. Several of the female converts expressed utter disenchantment with and distaste for the feminist movement. Typical is the statement by Aminah Benjelloun: "Through Islam I discovered my true value, my value as a woman" in Aminah Benjelloun, "Why I Am a Muslim," Islamic Horizons (September 1984): 6.

36. Rofe, "Islam," 35.

37. Howe, "Threshold," 33. 
